\title{
Role of Balinese Local Wisdom of Tourism Law Enforcement
}

\author{
I Dewa Made Suartha \\ Faculty of Law \\ University of Udayana \\ Denpasar, Indonesia \\ dewamarta9@gmail.com
}

\author{
I Dewa Agung Gede Mahardhika Martha \\ Faculty of Law \\ University of Warmadewa \\ Denpasar, Indonesia \\ fozzielboxer.gbloyality@gmail.com
}

\begin{abstract}
Law enforcement tourism amid the current globalization when is still very weak, because of the rules governing the implementation of tourism is still patterned, sectoral and economic interests are oriented in a moment. Implications for law enforcement less coordination, less supervision, less assertive and inconsistent set of rules that govern tourism. As a result the common conflict of interest in law enforcement. The potential of discernment local Balinese people have proven to be effective at keeping and maintaining environmental sustainability as cultural and natural tourism commodities thus less appropriate even sacrificed for the sake of portrayed tourism
\end{abstract}

Keywords-tourism; local wisdom

\section{INTRODUCTION}

Regulations governing tourism, such as: Act No. 9 of year 1990 with law No. 10 Year 2009, Government Regulation No. 67 Year 1996 and other regulations implementation, not accommodating hosts and business or tourism are increasingly globalizing [1].

Bali as a tourist center of the middle part and the door leading Indonesia Tourism developed. Agriculture as one sector is less observed, even likely to be sacrificed for the sake of tourism. Resulted in the development of tourism that is not well-ordered, bringing negative impact against the natural environment and culture, such as: rice, Garden, cliffs, hills and others have been turned into hotels, villa, café, restaurant, golf course and other attractions. Moreover, when the treated Act No. 32 Year 2004 about the autonomous region, there is a trend of local government authorities issued permit to build the facilities and attractions with exploiting natural resources and environment for the pursuit of a genuine regional revenue (PAD) and less power and support environmental sustainability regions [2].

Spatial Bali based Tri Hita Karana less philosophical note, physical development is done above the mountain, into the Lakes, rivers, beaches, deep ravines, on a hill by the Balinese people viewed as the sacred region purified, obviously interfere with the existence of the culture and belief/conviction of the Balinese. Other risks as a threat to Bali and Bali tourism also is a drop in the conservation values of religion, customs, social culture and the quality of the living environment of the community.

The clutter of development and the development of tourism, as one of the law enforcement (tourism) is still weak, less noticed and understands the local wisdom values alive in the community. In fact the local Balinese wisdom have effectively safeguard and maintain the sustainability of the natural environment and culture as tourism commodities, such as: Alas Kedaton in Tabanan, Gianyar on Cranes, Indigenous Villages Penglipuran in Bangli and others.

Based on preliminary descriptions above, then it can be formulated in this paper the problem as follows: 1) how the role of the wisdom of local Balinese people in law enforcement tourism amid the current globalization?, 2) How construction law enforcement to better portray the future tourism wisdom local Balinese people amid the current globalization?

\section{METHOD}

As a normative legal research, the method used in this study is a legislative approach that is integrated with a conceptual approach. It is caused, there is a void of norms by examining the materials of various laws and other materials from various literatures related to the problem

\section{RESULT AND DISCUSSION}

\section{A. The concept of Local Wisdom, Legal Tourism and Globalization}

Local wisdom, translated as intelligence, wisdom, cleverness that insightful to the fore, with lean on values, norms, ethics and behaviour of the work traditionally, in managing the various natural resources, culture and human resources for sustainable survival. Local wisdom can be conceptualized as part of culture, particularly the parts of traditional knowledge systems [3].

Tourism law, defined as a device set up everything related to tourism, including objects and tourist attraction, as well as all activities or efforts related to that field [1].

Globalization, defined as the activity of the already known worldwide, so that the boundaries between countries in a variety of such activities no longer valid [1] 


\section{B. Law Enforcement Tourism Amid the Current Globalization.}

The proper functioning of the law effectively defined by three components, namely: the substance of the law (legal substance), the structure of the law (legal structure) and the culture of the law (legal culture) [4]. This means that the function is not the law of tourism in tourism development is a very styling is determined by three components system of law, i.e. the material statutory tourism (the substance of the law), law enforcement (structure) and also awareness law (legal culture) are interlinked, the influence of affect and complement a totality [4].

From the study it was found that the material law No. 10 Year 2009 about tourism, have been explicitly set in general tourism as well as patronage towards the preservation of the natural environment and culture society as tourism commodities, but not yet embody and accommodate the interests of the increasingly globalizing tourism effort is, for example: related to the professionalization tourist business, competition, security of tourists, labour tourism and others [1].

The study results of tourism law enforcement three years, namely; from the year 2008-2011 in the city of Denpasar and Badung Regency showed, that; law enforcement structure of the subsystem, as tourism is still very weak. Offense was dominated by the issue of a license relating to construction and tourism services tourism amounted to 7060 (96\%) cases were resolved with non-litigation and 204 (4\%) cases were resolved by litigation. In non-litigation process settlement built by the section Controlling Spatial and Permitting as well as parts of act Police teachers ' Praja. Result only 20\% can be resolved completely with non-litigation and the remaining $80 \%$ still until now. While the litigation settlement with accomplished can be completely through the State court verdict Denpasar. The takeover of farmland for tourism has been exaggerated, so that related to the agricultural marginalized and farmers as its part also marginalized. Law enforcement is less coordination, less supervision, less assertive in law enforcement. Recognition section of the Spatial coordination often late from permitting Police and teachers ' Praja so otherwise. Even the police say teachers ' Praja new Act after a request from the Department concerned. Teachers ' Praja police should not have to wait for a request from the Department concerned, but rather as the leading guard overseeing implementation of Perda (tourism), so no need to crack down on the offense late. Finally the society increasingly daring violation, especially related to permitting. On the other chief of customary village in Sanur and Kuta has never been involved in law enforcement [5].

The fact is the role of the local Balinese wisdom has proven effective in keeping and maintaining the sustainability of the natural environment and culture as tourism commodities, even beyond the formal institutions/government role, for example: Alas Kedaton in Tabanan, Gianyar, Cranes at the customary of village Penglipuran in Bangli, Pekraman village of Tenganan in Karangasem, subak and others

While the subsystem of culture (cultural society) shows that; awareness of Community law can be either; habits, views, how to think and behave that they can shape the social forces that move with its own way of approaching (keep the) law or otherwise moving away from (breaking) law [4].

\section{CONCLUSION}

From the above discussion of introduction and description, then it can be summed up as follows:

- Law enforcement tourism in Sanur and Kuta town of Denpasar, Badung Regency are still very weak, lack of coordination, lack of assertive, less oversight and inconsistent to apply a provision of tourism.

- Construction of law enforcement, tourism already is a must to portray local wisdom the Balinese, as has been proven to effectively maintain and preserve the natural environment and its sustainability as a tourism commodity, as example: Alas Kedaton in Tabanan, Cranes at the Customary Village of Petulu in Gianyar, Customary Village Of Tenganan in Karangasem and others advice

From the above discussion and a summary description, then it can be advised as follows:

- The reinterpretation of the function and meaning of local wisdom the Balinese in the protection and preservation of the natural environment and culture as a commodity of tourism.

- The transformation potential of discernment of the local Balinese people in local regulations in the field of tourism.

- Integration and adaptation of local Balinese wisdom in dispute resolution.

- The revitalizing potential of Balinese local wisdom in maintaining security and order tourism activities.

\section{ACKNOWLEDGEMENT}

The author would like to thank all the parties who have helped and contributed in the writing of this article, both those who contribute in the form of funding and critical ideas. Hopefully this paper can be useful theoretically and practically for the addition and development of knowledge, especially in the field of legal science.

\section{REFERENCE}

[1] I. B. W. Putra, Bali in a Global Persfektif, Upada literature, Denpasar. 1998.

[2] I. G. Pitana, fight for autonomous region: prevent Sandyakalaning Bali tourism Bali Post, reader, Denpasar. 2004.

[3] Griya, local wisdom In Persfektif Cultural Studies Association Teoritik And the realm of Applicative, Masters Program in cultural studies, University of Udayana, Denpasar. 2004.

[4] L. M. Friedman, The Legal System, A Social Sceince Perspective, Russell Sage Foundation, NewYork. 1980. 
[5] D. Suartha, the role of local wisdom Balinese people in law enforcement in Te First Globalization Services Current ngah, research report, funded from Project Nuffic IDN 223 fiscal year 2011 Research Agreement, letter 07/Research/NPT-Nuffic-FL-
2011/II/UDAYANAUNIVERSITY, Faculty of law, University of Udayana, Denpasar. 2011. 